\title{
An Approach to Measuring the Performance of a Large-Scale Collaboration
}

\author{
Ronald C. Beckett \\ Centre for Industry and Innovation Studies (CInIS), \\ College of Business, University of Western Sydney, Australia \\ r.beckett@uws.edu.au
}

\begin{abstract}
Large-scale collaborations such as business networks and clusters are being promoted worldwide, but some OECD studies suggest that measuring the performance of such collaborations can be problematic. In this paper a grounded theory approach leads to the proposition that important attributes of a large-scale collaboration are its dimensions, maturity and relative heterogeneity of participants; whilst critical outcomes from a large-scale collaboration initiative are balanced housekeeping/beneficial transactions and improved market access/competitiveness. This proposition is used to demonstrate business process frameworks for characterizing and measuring the performance of such collaborations.
\end{abstract}

Keywords: Performance Measurement, Virtual Organisations, Clusters.

\section{Introduction}

Around the world, governments are stimulating large-scale collaborations such as business networks and clusters to improve the competitiveness of regions. The intention is to encourage networking between actors, to stimulate networks of activities and to build on clusters of resources, facilitating innovation and enhanced market access. In researching the dynamics of markets, the IMP group [1] has found it useful to characterize markets as intersecting networks of actors, resources and activities (ARA theory). In considering the research question "Can we identify a simple way of measuring the performance of a large-scale collaboration?" we draw on some literature on virtual enterprises and clusters and combine it with observations about multipartner collaborations and the ARA theory literature.

\section{Some Observations from Prior Case Studies and the Literature}

We are taking a grounded theory approach in this research, combining observations from nine case studies we have described elsewhere with observations from the literature to identify categories of observations and some related properties using an ARA theory framework in the context of our research question. 
The nine cases represented a cross-section of different kinds of collaboration. Three kinds of actors were involved. Firstly; sponsors (7/9 had some form of government support, 5/9 involved industry associations). Secondly; facilitators (5/9 were facilitated by some kind of industry association, 2/9 by individuals and in 2/9 cases a separate administration group was formed). Finally, contributors (generally SMEs, but in two cases micro businesses were the dominant group). Camarinha-Matos and Afsarmanesh [2] have observed a number of characteristic contributor roles associated with collaboration operations: focal firms, technology providers, local networks, communities of practice and supporting firms. These were all observed in the nine cases, although not all were necessarily present in a particular case.

Four kinds of joint activities were identified: activities that required collaboration to build scale (3/9 cases), activities that required collaboration to build scope $(5 / 9$ cases) activities supporting enhanced innovation through collaboration (4/9 cases), activities to enhance market access through collaboration (7/9 cases).

Three kinds of resource sharing were observed: firstly, access to a combination of somewhat unique physical assets (e.g. special production machinery or experimental equipment) and financial resources (e.g. government grants) (7/9 cases). Secondly, access to intellectual assets (both technological know-how and business know-how) (6/9 cases). Finally, participation in events that enhanced social capital (e.g. sharing access to personal networks, building networking skills) (9/9 cases).

Some selected examples of different perspectives found in the literature follow. A recent OECD report on clusters [3] suggested that measurement of performance was difficult, and not even attempted in many cases. Where measurement was attempted, there were commonly two separate kinds of measure. The first, and most common, assessed the operation of the collaboration - who got involved, what kinds of things were happening and was it developing and operating to plan. The second, and least common, considered the impact of collaborating. In the latter case, data collection could become a significant task, and being able to confidently appropriate particular benefits to the collaboration could be problematic [4]. Government sponsored programs were stimulated by one or more of three different policy areas: regional development, innovation and industry sector capability development, with economic growth being a common objective.

In studying the outcomes of a mid 1990's Australian Government initiative that encouraged small firms to form about 80 business networks, Marceau [5] noted firstly, that most did not persist after Government support was curtailed, and secondly, that the commercial outcome was more influenced by their success in engaging with the market than by their internal working arrangements.

Taken together with other references, this leads us to the list of categories and properties shown in Table 1, which we have characterised as either attributes (something about the collaboration) or critical success factors (something related to its likely impact). The outcome is a proposition that the important attributes of a largescale collaboration are dimensions, maturity and heterogeneity of participants; whilst outcomes from a large-scale collaboration are improved market access / competitiveness and balanced housekeeping and beneficial transactions. In the following 
sections of this paper these two factors will be used in combination with other theories to first characterise a large-scale collaboration, then propose a performance measurement approach.

Table 1. Some Categories and their Properties Emerging from the Grounded Theory Approach to Collaboration Characterization and Performance Measurement

\begin{tabular}{|c|c|}
\hline $\begin{array}{c}\text { Performance } \\
\text { Measurement Categories }\end{array}$ & Properties of the Category \\
\hline $\begin{array}{l}\text { Attribute - Dimensions } \\
\text { (Size and scope of participant } \\
\text { organizations influences the } \\
\text { dominant nature of engagement) }\end{array}$ & $\begin{array}{l}\text { - Geographical scope, relative concentration of firms, variety of } \\
\text { products in different but related industries, range of value adding } \\
\text { activities, growth potential, (e.g. [6, 7] } \\
\text { - Number of firms involved, size of firms and revenue, spending on } \\
\text { innovation (e.g. [4]) }\end{array}$ \\
\hline $\begin{array}{l}\text { Attribute - Maturity } \\
\text { (emergent firms and emergent } \\
\text { collaborations require additional } \\
\text { support) }\end{array}$ & $\begin{array}{l}\text { - Life-cycle of collaboration perspective (e.g. [8]) } \\
\text { - Experience in collaborating perspective (e.g. [9]) } \\
\text { - Maturity of collaborating firms (e.g. [10]) }\end{array}$ \\
\hline $\begin{array}{l}\text { Attribute } \\
\text { Heterogeneous } \\
\text { participants } \\
\text { (Need to enact key roles and } \\
\text { balance contributions) }\end{array}$ & $\begin{array}{l}\text { - Collaboration managers need to enact key roles (e.g. [11]) } \\
\text { - Roles of participants need to be understood - e.g. focal firm, } \\
\text { technology provider, supporting firm - }\{2\} \\
\text { - Need to balance similarity and complementarity attributes of } \\
\text { participants (e.g. }[12,13]\end{array}$ \\
\hline $\begin{array}{l}\text { Critical Success Factor - } \\
\text { Market Access \& } \\
\text { Competitiveness } \\
\text { (No access, no outcome) }\end{array}$ & $\begin{array}{l}\text { - Able to effectively engage with markets (e.g. [5]) } \\
\text { - Able to be competitive, at least regionally (e.g. [7,14]) } \\
\text { - Able to adapt to changing circumstances (e.g.[15]) - cluster } \\
\text { absorptive capacity (e.g. [16]) }\end{array}$ \\
\hline $\begin{array}{l}\text { Critical Success Factor - } \\
\text { Transactions } \\
\text { (Transactions are the life-blood } \\
\text { of collaborations - no } \\
\text { transactions, no outcomes, and } \\
\text { they may have negative or } \\
\text { positive effects. In a commercial } \\
\text { enterprise revenue exceeds costs } \\
\text { to yield a profit. We apply the } \\
\text { same principle to value-adding } \\
\text { and non-value adding } \\
\text { transactions) }\end{array}$ & $\begin{array}{l}\text { - Collaboration housekeeping transaction are required, but have a } \\
\text { negative value, which must be offset by beneficial transactions } \\
\text { (e.g. [17]) } \\
\text { - Social transactions build social capital that facilitates other kinds } \\
\text { of transactions and learning (e.g. via a breeding network - }[2] \text { ) } \\
\text { - Stimulating knowledge generation and knowledge flows creates } \\
\text { knowledge capital that may be used to enhance competitiveness } \\
\text { (e.g. [18]; via a community of practice - [2] } \\
\text { - Economic transactions enhance profitability and build economic } \\
\text { capital (e.g. via a virtual enterprise - [5;19)) }\end{array}$ \\
\hline
\end{tabular}

\section{Characterising a Large-Scale Collaboration}

Large-scale collaborations are characterized by actor-centric personal networking, sharing access to a network of resources, and supplementing a firm's traditional network of activities with additional networks of cooperative activities. Accessing markets traditionally involves working with networks of actors (customers and suppliers), networks of resources within and external to a firm (suppliers) and activities associated with the value chain, as observed by the IMP Group [1]. In Table 2 an approach to characterizing the performance of a large-scale collaboration is described by combining the categories from Table 1 with an ARA perspective. 
Table 2. Characterizing the performance of a large-scale collaboration

\begin{tabular}{|c|c|c|c|}
\hline \multirow{2}{*}{$\begin{array}{c}\text { Performance } \\
\text { Measurement } \\
\text { Categories }\end{array}$} & \multicolumn{3}{|c|}{ Measures of performance } \\
\hline & Actors & Resources & Activities \\
\hline $\begin{array}{l}\text { Attribute } \\
\text { Dimensions } \\
\text { (Size and scope of } \\
\text { participant organizations } \\
\text { influences the dominant } \\
\text { nature of engagement) }\end{array}$ & $\begin{array}{l}\text { - Number of firms } \\
\text { involved, size of } \\
\text { firms and revenue }\end{array}$ & $\begin{array}{l}\text { - Geographical scope, } \\
\text { relative concentration } \\
\text { of firms, } \\
\text { - variety of products } \\
\text { in different but related } \\
\text { industries } \\
\text { - Growth potential }\end{array}$ & $\begin{array}{l}\text { - Scope of participant } \\
\text { value adding activities, } \\
\text { - Participant spending } \\
\text { on innovation }\end{array}$ \\
\hline $\begin{array}{l}\text { Attribute } \\
\text { Maturity } \\
\text { (Emergent firms and } \\
\text { emergent collaborations } \\
\text { need additional support) }\end{array}$ & $\begin{array}{l}- \text { Relative business } \\
\text { maturity } \\
\text { participating firms } \\
-\quad \text { Experience in } \\
\text { collaborating }\end{array}$ & $\begin{array}{l}\text { - Relative maturity of } \\
\text { participating firms } \\
\text { knowledge base } \\
\text { - Relative maturity of } \\
\text { participating firms } \\
\text { physical resources } \\
\end{array}$ & $\begin{array}{l}\text { - Life-cycle view of } \\
\text { collaboration } \\
-\quad \text { Maturity stage } \\
\text { reached in breeding } \\
\text { network and spin-offs, } \\
\text { projects }\end{array}$ \\
\hline $\begin{array}{l}\text { Attribute } \\
\text { Heterogeneous } \\
\text { participants } \\
\text { (Need to enact key } \\
\text { roles and balance } \\
\text { contributions) }\end{array}$ & $\begin{array}{l}\text { - Ownership of and } \\
\text { commitment to the } \\
\text { collaboration at } \\
\text { multiple levels } \\
\text { - Diversity of } \\
\text { participant } \\
\text { professions }\end{array}$ & $\begin{array}{l}\text { - Balanced similarity } \\
\text { and complementarity } \\
\text { attributes of } \\
\text { participant activities } \\
\text { and resources }\end{array}$ & $\begin{array}{l}\text { - Need to enact key } \\
\text { administration roles e.g. } \\
\text { relationship and task } \\
\text { management } \\
\text { - Roles of participants } \\
\text { need to be understood - } \\
\text { e.g. focal firm, } \\
\text { technology provider, } \\
\text { supporting firm }\end{array}$ \\
\hline $\begin{array}{l}\text { Critical } \quad \text { Success } \\
\text { Factor - } \\
\text { Access } \\
\text { Competitiveness } \\
\text { (No access, no outcome) }\end{array}$ & $\begin{array}{l}\text { - Able to be } \\
\text { competitive, at least } \\
\text { regionally }\end{array}$ & $\begin{array}{l}\text { - Able to adapt re- } \\
\text { sources to changing } \\
\text { circumstances } \\
\text { - Cluster absorptive } \\
\text { capacity }\end{array}$ & $\begin{array}{l}\quad \text { Processes to to } \\
\text { effectively engage with } \\
\text { markets }\end{array}$ \\
\hline $\begin{array}{l}\text { Critical Success } \\
\text { Factor } \\
\text { Transactions } \\
\text { (Transactions are the life- } \\
\text { blood of collaborations - } \\
\text { no transactions, no out- } \\
\text { comes, and they may } \\
\text { have negative or positive } \\
\text { effects) }\end{array}$ & $\begin{array}{l}\text { - Kinds of social } \\
\text { capital } \\
\text { (competence built } \\
\text { contract / goodwill } \\
\text { based trust; bonding / } \\
\text { bridging / linking } \\
\text { relationships) } \\
\text { - Kinds of knowledge } \\
\text { capital built } \\
\text { (technical / market, } \\
\text { tacit / codified) }\end{array}$ & $\begin{array}{l}\text { - A clear cost-benefit } \\
\text { in relation to the } \\
\text { investment in cluster } \\
\text { resources and ways } \\
\text { that the participant } \\
\text { foundation resources } \\
\text { are used more } \\
\text { effectively through } \\
\text { collaboration } \\
\text { - Circumstances for } \\
\text { sharing physical and } \\
\text { knowledge resources }\end{array}$ & $\begin{array}{l}\text { - Housekeeping trans- } \\
\text { actions that add value } \\
\text { - Social transactions } \\
\text { that build trust and } \\
\text { linkages } \\
\text { - Knowledge generation } \\
\text { transactions and } \\
\text { knowledge flows } \\
\text { - Economic transactions } \\
\text { enhance profitability } \\
\text { and build economic } \\
\text { capital }\end{array}$ \\
\hline
\end{tabular}

Hofmann [20] suggested that a stakeholder value-added approach be taken to considering network performance. Different stakeholders are likely to see a particular collaboration in different ways. An OECD report [3] on competitive regional clusters stated that "A cluster member is presumably more interested in the overall cluster's competitive position than in the cost-effectiveness of a particular public policy action. A cluster initiative manager may be most interested in success at bringing actors together in joint activities and the development of stronger economic and social relationships. A politician may need to know how many jobs were created or how much 
the region's economy has improved". The political perspective will also depend on the administering policy area (regional development policy / science \& innovation policy / industry sector development policy).

A Canadian study [4] primarily concerned with science-driven clusters put the individual firm and its performance in a central position, with influences from customers, competitors and supporting organizations plus a number of environmental factors. The argument is that impact is primarily driven by firm performance in its market context. Environmental factors such as natural resources may have some direct influence on outcomes, but environmental factors (such as establishing a large-scale collaboration) more often have an indirect influence on outcomes through the firm. This is the view taken in constructing Table 2, where some items are highlighted in italics to suggest those considered by the author to have the greatest impact.

In assessing a particular collaboration, the existence or otherwise of some of the features suggested in Table 2 and some quantification of these features will build an understanding of it's particular strengths and weaknesses, leading to ideas for improvement. Not addressing one of these features may be a fatal flaw.

\section{Measuring the Impact of a Large-Scale Collaboration}

To consider the impact of a large-scale collaboration we view it as a supplementary business ecosystem that is a light over-lay on the participant's normal (networked) business environment. Business activity arising through the cluster will generally provide some, but not all of a firm's total business. In this context, using a systems perspective [21] we characterise this overlay as follows:

- The collaboration is a business process having models of action and internal processes [22] seeking to provide benefits for the participants and the broader community and having some subsystems related to its own operations and some subsystems related to participant operations. Some process activities may be short term and some may be long term.

- Inputs to the process are the collaboration vision and intentions [22] plus business opportunities. Deficiencies in either of them will compromise the process

- $\quad$ Outputs from the process may be measured in terms of economic capital, knowledge capital and social capital, enhanced capability, lessons learned, and broader community benefits such as job creation. There may be spillover benefits to nonparticipants. If there are no outputs the process has failed

- Rules / constraints in terms of government policy, the business environment, competitive pressures and a customer perspective [22] condition process operations as well as less formal conditions like trust and equity [23]

- Resources to make the process work include cluster facilitation resources and participant capabilities [22]

Combining these ideas with some of the features identified in Table 2, and using a mapping tool [21], a business process representation of a large-scale collaboration was constructed, as shown in Figure 1. 


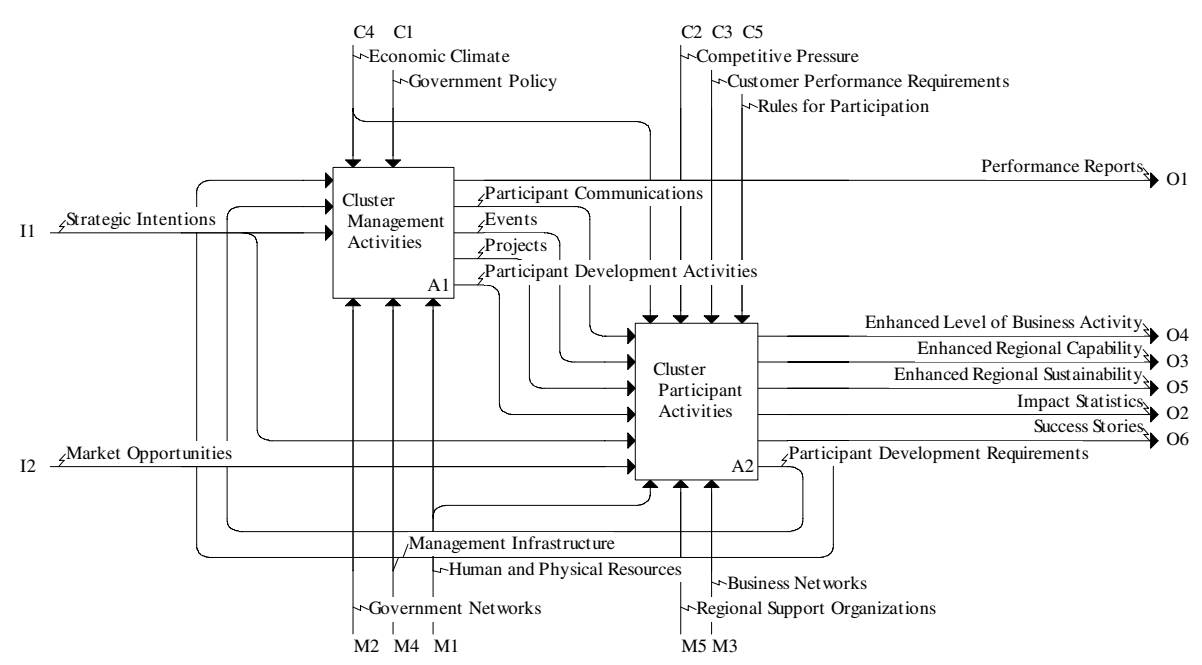

Fig. 1. A Representation of a Large-scale Collaboration as a Business System

A number of researchers (e.g. [24]) have noted that there may be a significant time lag between an input and an observable output, for example while absorptive capacity is built [16]. In addition, as a collaboration is an overlay on a participant's normal activities, it may be difficult to attribute outcomes to and spillovers from participation. Some researchers have compared the performance of collaboration participants with a control group, sometimes reporting a superior rate of growth, sometimes reporting no effect. One difficulty here is knowing whether the participating firms are the more innovative ones anyway. Swedish experience [24, 3] suggests that annual internal reviews plus an external review every three years may be appropriate. Evaluation should have a number of elements: firstly, identification of objectives and the relevant policy framework; secondly, selection of evaluation criteria; thirdly, monitoring over the life of the collaboration, fourthly a formal evaluation process, and finally, feedback and implementation of lessons learned.

Neely [25] has undertaken a comprehensive review of more than 30 years of research into business performance measurement. Whilst annual financial reporting has been the historical norm, a balanced scorecard [26] approach using key performance indicators to link strategy and measurement has been popular over the last 20 years. More recently, Kaplan [27] has suggested that achieving the vision should take precedence over financial measures in not-for- profit enterprises

Combining the collaboration-as-a-business system view with the suggestions above and some presented earlier, a set of key performance indicators appropriate to a long term breeding network environment is proposed in table 3. For shorter term collaborations where a virtual enterprise may be established for a specific project, successful completion of the project may be an adequate measure of collaboration performance, but this would not identify any gains in social or knowledge capital and lessons learned. Capturing these things in an annual survey as part of the collaboration management strategy may surface such outcomes. 
Table 3. Some Illustrative Key Performance Indicators

\begin{tabular}{|c|c|c|}
\hline KPI Type & KPI & Measure \\
\hline \multirow[t]{5}{*}{ Process } & $\begin{array}{ll}\text { Cluster management } & \text { operations } \\
\text { according to plan } & \\
\end{array}$ & Annual internal review \\
\hline & Events held & $\begin{array}{l}\text { Annual reporting of number, type and } \\
\text { attendance }\end{array}$ \\
\hline & Projects established & $\begin{array}{l}\text { Annual reporting of number started, } \\
\text { finished and in progress with } \\
\text { comment on issues and opportunities }\end{array}$ \\
\hline & Individual firm services provided & $\begin{array}{l}\text { Annual reporting of firms assisted } \\
\text { and outcomes from the CRM system }\end{array}$ \\
\hline & Member activities & $\begin{array}{l}\text { Annual reporting of participation } \\
\text { rates and firm profiles plus } \\
\text { outstanding member activities and } \\
\text { achievements }\end{array}$ \\
\hline \multirow[t]{2}{*}{ Input } & $\begin{array}{l}\text { Clear cluster vision and statement of } \\
\text { intentions developed in conjunction } \\
\text { with stakeholders }\end{array}$ & $\begin{array}{l}\text { Annual reporting of progress against } \\
\text { intentions, Review every three years }\end{array}$ \\
\hline & Identification of business opportunities & $\begin{array}{l}\text { Annual reporting of significant } \\
\text { opportunities available to the cluster }\end{array}$ \\
\hline \multirow{6}{*}{ Outputs } & Economic benefits & From an annual member survey \\
\hline & Member capability enhancements & From an annual member survey \\
\hline & Knowledge flows & Annual reporting of lessons learned \\
\hline & Collaborations established & From an annual member survey \\
\hline & Jobs created & From an annual member survey \\
\hline & Spillover benefits & $\begin{array}{l}\text { Anecdotal evidence noted in annual } \\
\text { report }\end{array}$ \\
\hline \multirow{3}{*}{$\begin{array}{l}\text { Rules / } \\
\text { constraints }\end{array}$} & Alignment with Government policy & Review every three years \\
\hline & Business environment & Impact statement in annual report \\
\hline & Competitive pressures & Impact statement in annual report \\
\hline \multirow[t]{2}{*}{ Resources } & Cluster management resources & $\begin{array}{l}\text { Annual report reviewing resources } \\
\text { used, opportunities for improvement } \\
\text { and the level of resourcing }\end{array}$ \\
\hline & Cluster member resources & $\begin{array}{l}\text { Annual report summarizing member } \\
\text { cash and in-kind contributions }\end{array}$ \\
\hline
\end{tabular}

\section{Illustrative Application of the Concepts}

In February 2009 The University of Western Sydney Centre for Industry and Innovation Studies conducted an external review of the Western Sydney Information Technology Cluster (WSITC) that had been operating since 2001. The process involved a review of relevant documents and some literature on clusters plus direct interaction with the cluster managers and participants. A brief on-line member survey yielded fourty-seven responses, there were interviews with eight member firms, two focus group meetings were held, one with government participants, and the other with member participants.

Using ideas from Tables 2 and 3 to characterise the collaboration, the outcome was as follows:

- Dimensions - there are about 230 full members (still increasing by about 30 members each year) with a combined annual turnover of about $\$ A 700 \mathrm{~m}$ plus 
100 associate members. $70 \%$ are located inside of a $20 \mathrm{~km}$ diameter circle. $60 \%$ of the member firms have less than five employees, and there are no large firms in the cluster. Most member firms are focused on IT applications rather than new technology development. About $60 \%$ own some form of intellectual property. About one-third of both the micro-firm and the SME firms plan to grow over the next five years.

- Maturity - the majority of the participants are either still growing their core business or learning more about exporting. Member firms do not tend to be continuously engaged, participating more during growth periods. A breeding network is well established, but there are relatively few projects.

- Heterogeneous participants - The 100 associate member enterprises provide a variety of education, business, market and technology support services, and this helps the developing member firms. The member firm clientele is commonly spread over seven different market sectors. Balancing similarity and complementarity seems to be an issue.

- Market access and competitiveness - strong growth in export activity since the cluster was established suggests that some firms are competitive, but the smaller firms have difficulty in accessing larger government projects. Absorptive capacity is an issue for some member firms, due to both knowledge and resource limitations.

- Transactions - considerable social capital and knowledge capital has been built. There is limited evidence of economic transactions between or in conjunction with member firms. Government funded housekeeping transaction management undertaken is appreciated by the members

- Process (from Table 3) - The cluster is achieving its original objectives. A significant number of cluster events are held each year, but there a few spinoff projects. About $60 \%$ of the members attend two or three events each year, whilst the remainder did not attend any in 2008 .

- Inputs - There is a statement of intentions that is currently under review, and some business opportunities are identified for members.

- Outputs - In our member survey, about $27 \%$ of micro-firms and $33 \%$ of SMEs reported revenue enhancement associated with the WSITC, but approximately double that reported other benefits to their business arising from participation. We interpret this as meaning that whilst some firms are getting direct benefits from the WSITC, the dominant benefit is back in the firm's primary business eco-system. There was clear evidence of member capability enhancement attributed to cluster participation, a significant number of jobs created, and some evidence of spillover benefits to cluster client firms.

- Rules/constraints - There was evidence of alignment with government policy and significant competitive market pressure

- Resources - members were satisfied with the cluster management resources, and many member and associate member firms were making in-kind contributions. 


\section{Concluding Remarks}

We began with the research question "Can we identify a simple way of measuring the performance of a large-scale collaboration?" The suggested answer is - firstly establish a way to simply characterize such collaborations. Our proposition is that the important attributes of a large-scale collaboration are dimensions, maturity and heterogeneity of participants; whilst outcomes from a large-scale collaboration are improved market access / competitiveness and balanced housekeeping and beneficial transactions. Secondly, view operation of a large-scale collaboration as a business process that can be modeled, and using the characterization guidelines and this model, suggest some key performance Indicators. Finally, using this framework, go and talk to the participants. Using this approach in the illustrative case briefly presented in the paper, benefits that the government sponsors were not aware of were identified, as were many opportunities for improvement that had not been discussed. The data collected also supported some comparison with other clusters.

\section{References}

1. IMP (2009), http: / / www . impgroup. org / about .php (last accessed February 27, 2009)

2. Camarinha-Matos, L.M., Afsarmanesh, H.: The Emerging Discipline of Collaborative Networks. In: Camarinha-Matos, L.M. (ed.) Virtual Enterprises and Collaborative Networks, pp. 3-16. Kluwer Academic Publishers, Dordrecht (2004)

3. OECD. Competitive Regional Clusters - National policy Approaches, Organisation for Economic Co-operation and Development (2007) ISBN 978-92-64-03182

4. Cassidy, E., Davis, C., Arthurs, D., Wolfe, D.: Measuring the National Research council's Technology Cluster Initiatives. Presented at the CRIC Cluster Conference, Beyond Cluster - Current Practices and Future Strategies, Ballarat, Australian June 30-July 1 (2005)

5. Marceau, J.: Networks of Innovation, Networks of Production and Networks of Marketing: Collaboration and Competition in the Biomedical and Toolmaking Industries in Australia. Creativity and Innovation Management 8(1) (1999)

6. Enright, M.J.: Survey on the characteristics of regional clusters - initial results, Working Paper, Institute of Economic Policy and Business Strategy, Competitiveness Program, University of Hong Kong (2000)

7. Laitinen, E.K.: Financial statement analysis of a network of SMEs: towards measurement of network performance. International Journal of Networking and Virtual Organisations 3(3), 258-282 (2006)

8. ISO 1507. Requirements for enterprise reference architectures and methodologies. Annex A - GERAM: Generalized Enterprise Reference Architecture and Methodologies, Integration definition for function modelling (IDEF 0) US Federal Information Processing Standard publication 183 (1993)

9. Beckett, R.C.: Building Social Capital in the Australian Toolmaking Industry. In: Proc. 2nd meeting of IMP group in Asia, Building social capital in networks, Phuket, Thailand, December 12-14 (2005) ISBN 1740674251

10. Fornahl, D., Menzel, M.-P.: Co-development of firm founding and regional clusters. In: Proc. Clusters, Regional Districts and Firms: The Challenges of Globalization, Modena, Italy, September 12-13 (2003) 
11. Lipnack, J., Stamps, J.: Virtual Teams - People Working Across Boundaries with Technology. John Wiley \& Sons, New York (2000)

12. Biggiero, L., Sammarra, A.: Similarity and complementarity in inter-organisational networks. In: APROS (Asia-Pacific Researcher in Organisation Studies), Hong Kong Baptist University, December 3-5 (2001)

13. Inganas, M., Hacklin, F., Pluss, A., Marxt, C.: Knowledge management with a focus on the innovation process in collaborative networking companies. International Journal of Networking and Virtual Organisations 3(3) (2006)

14. Chapple, K.: Building Institutions from the Region Up: Regional Workforce Development Collaboratives, Working Paper 2005-01, Institute for Urban and Regional Development, University of California, Berkeley, CA (2005)

15. Seifert, M., Eschenbaecher, J.: Predictive performance measurement in virtual organizations. In: Emerging Solutions for Future Manufacturing Systems, pp. 299-306. Springer, Boston (2005)

16. Giuliani, E.: Cluster Absorptive Capability: An evolutionary approach for industrial clusters in developing countries. In: Proc. DRUID Summer Conference Industrial Dynamics of the New and Old Economy - who is enhancing whom? Copenhagen, June 6-8 (2002)

17. Beckett, R.C.: The Evolution of Some Collaborative Marketing Networks of SME's. In: 22nd Industrial Marketing \& Purchasing (IMP) Conference, Milan, Italy, September 7-9 (2006)

18. Okkonen, J.: Performance of Virtual Organisations. In: Frontiers of e-Business research 2001, University of Tampere, e-Business Research Centre, Finland (2001) ISBN 951-445307-7

19. Camarinha-Matos, L.M., Abreu, A.: Performance indicators based on collaboration benefits. In: Collaborative Networks and their Breeding environments, pp. 273-282. Springer, New York (2005)

20. Hofmann, E.: Quantifying and setting off network performance. International Journal of Networking and Virtual Organisations 3(3), 317-339 (2006)

21. AIØWIN Automated Function Modelling for Windows, Knowledge Based Systems Inc.

22. Varamaki, E., Kohtamaki, M., Sorama, K., Wingren, T., Versalainen, J., Helo, P., Tuominen, T., Pahkala, T., Tenhunen, J.: A framework for a network-level performance measurement system in SME networks. International Journal of Networking and Virtual Organisations 5(3/4), 415-435 (2008)

23. Saiz, J.J.A., Rodriguez, R., Bas, A.O.: Performance measurement system for virtual and extended enterprise. In: Collaborative networks and their breeding environments, pp. 285 292. Springer, Boston (2005)

24. IKED, The Cluster Policies Whitebook" The International Organisation for Knowledge Economy and Enterprise Development, Sweden, 247 pages (2004) ISBN 91-85281-03-4

25. Neely, A.: The evolution of performance measurement research. International Journal of Operations and Production Management 25(12), 1264-1277 (2005)

26. Kaplan, R., Norton, D.: The balanced scorecard - measures that drive performance. Harvard Business Review, 71-79 (January-February 1992)

27. Kaplan, R.S.: Strategic performance measurement and management in nonprofit organizations. Nonprofit Management \& Leadership 11(3), 353-370 (2001) 